\title{
Geochemistry of Persististrombus latus Gmelin from the Pleistocene Iberian Mediterranean realm
}

\author{
TRINIDAD DE TORRES, JOSÉ E. ORTIZ, ISABEL ARRIBAS, ANTONIO DELGADO, RAMÓN JULIÀ AND \\ JUAN A. MARTÍN-RUBÍ
}

\begin{abstract}
In this paper the organic and inorganic geochemistry of fossil and extant Persististrombus latus are compared, together with other strombid species (Lentigo lentiginosus, Lobatus gigas, Strombus alatus, Lobatus raninus, Laevistrombus canarium and Tricornis latissimus). Using a large sample of well-preserved fossil P. latus shells from the Mediterranean realm, we examined the warming period of sea water in the Middle Pleistocene. A mineralogical study of the shells demonstrates the continuous presence of calcite and a complex organic matter distribution, which was well preserved in many cases, thereby making the $\mathrm{U} / \mathrm{Th}$ dating of strombid shells unreliable. $\mathrm{U} / \mathrm{Th}$ analysis of coral samples and amino acid racemization dating of pelecypod shells confirmed that $P$. latus entered the Mediterranean realm in MIS 7 and 5 . The oscillations of the $\delta^{18} \mathrm{O}$ values reflect annual growth periods and provide a mixing of the first signal record (primary growth) and successive overgrowths. $\square$ Amino acid racemization, Mediterranean Sea, Persististrombus latus, shell mineralogy, $U / T h, \delta^{18} \mathrm{O}$.
\end{abstract}

Trinidad de Torres[trinidad.torres@upm.es], José E. Ortiz [joseeugenio.ortiz@upm.es] and Isabel Arribas [isabelkitina.arribas@upm.es], Biomolecular Stratigraphy Laboratory, E.T.S.I. Minas, Universidad Politécnica de Madrid, C/Ríos Rosas 21, 28003 Madrid, Spain; Antonio Delgado [antodel@eez.csic.es], Estación Experimental de El Zaidín (CSIC), C/ Profesor Albareda 1, 18008, Granada, Spain; Ramón Julià [r.julia@ija.csic.es], Instituto de Ciencias de la Tierra "Jaume Almera" (CSIC), $C /$ Lluis Solé i Sabarís s/n, 08028 Barcelona, Spain; Juan A. Martín-Rubi [ja.martin@igme.es], Instituto Geológico y Minero de España, C/Ríos Rosas 23, 28003 Madrid, Spain;

Persististrombus latus Gmelin 1791 is the most cited fossil gastropod from the Pleistocene marine-raised deposits of the Mediterranean realm. It has usually been referred to as Strombus bubonius Lamarck 1822, although Strombus latus Gmelin 1791 is the senior synonym. However, according to the recent taxonomic revisions of Strombus species undertaken by Kronenberg \& Lee (2007) and Harzhauser \& Kronenberg (2008), this gastropod is considered to belong to the genus Persististrombus.

According to Cuerda (1987), the association of $P$. latus with other mollusc species constituted the Senegalese Faunal Complex, marking Mediterranean seawater warming during interglacial episodes along the Pleistocene, which corresponded to periods of high sea levels. In fact, today P. latus is restricted to the Eastern Atlantic Region, occurring in an area from the Rio d'Oro to Angola and limited in the north by the Canary Current and in the south by the Benguela Current. Its northern distribution borders are the Cape Verde Islands (Kreipl \& Poppe 1999). An average temperature of $25^{\circ} \mathrm{C}$ favours this gastropod; however, it tolerates a temperature range from 16 to $31^{\circ} \mathrm{C}$. Its average lifespan of $3-5$ years is characterized by a cyclic growth rate, depending on the seasonality of the sea surface temperature.

Due to its reproductive strategy, extant $P$. latus is a gregarious species (Stoner 1994; Mendes-Lopes 2002). The continuous presence of fossil $P$. latus lumachelle, a paucispecific tanatocoenosis linked to storm beach deposits, reinforces the notion that fossil $P$. latus inhabited shallow waters (Meco 1977).

Extant $P$. latus inhabit sandy-muddy bottoms and seagrass meadows and follows detritivorous and vegetarian feeding strategies (Lozac'hmeur \& Mascarenhas 1985), typically in waters with normal salinity (Guerreiro 1994; Guerreiro \& Reiner 2000; MendesLopes 2002). However, in the Gulf of Guinea, Meco (1977) found P. latus representatives in zones with freshwater input and consequently lower salinity. Although P. latus inhabits soft bottoms, our findings demonstrate that fossil $P$. latus also colonized rocky bottoms.

Strombid shells are made of calcium carbonate, with aragonite being the dominant polymorph, while other polymorphs such as calcite and vaterite are 
scarce or even absent (Abatino et al. 1971; GonzálezDelgado et al. 1998). In fact, the absence of calcite in $\mathrm{X}$-ray analyses of fossil shells is considered a reliable indicator of isotopic signal ( $\mathrm{O}$ and $\mathrm{C}$ ) preservation. Cornu et al. (1993) reported that calcite accounts for $2 \%$ of the weight of fossil P. latus shells, while other authors (Abatino et al. 1971; González-Delgado et al. 1998) simply attest to the lack of calcite in X-ray analyses. Moreover, Kamat et al. (2000) observed that the three layers that comprise Strombidae shell structure (outer, middle and inner mineralized layers) consist of first-, second- and third-order lamellae made of aragonite separated by organic matter within interfaces.

According to Weiner (1984) and Falini et al. (2000), the organic matrix (OM), ca. 1\% in Lobatus gigas (Linnaeus 1758) (Kuhn-Spearing et al. 1996), performs an active role in crystal growth, which are constituted by a core of hydrophobic proteins and surface layers of acidic proteins and polysaccharides. By contrast, Giles et al. (1995) contest the contribution of the OM to crystals formation. After nucleation, which included a template of acidic proteins, it was found that aragonite crystals grew inorganically in the extrapallial space, without direct biological control. The supersaturation levels required for overgrowth can be quite low because the cells of the mantle regulate the process by adjusting carbonate concentration and $\mathrm{pH}$ in the extrapallial fluid. Wada et al. (1993) observed that after the formation of aragonite nuclei, these undergo a solid-to-solid transformation into more stable calcite nuclei by absorbing components of organic matter, thus making the formation of calcite nuclei unnecessary. However, compared with geological aragonite, biogenic aragonite reveals lattice distortions because of the presence of organic macromolecules (Pokroy et al. 2000).

Persististrombus latus is considered to be a biomarker of the Tyrrhenian stage, although this term is under debate and it remains to be established whether it should be used as a climatostratigraphic or chronostratigraphic (linked to the Marine Isotope Stage, MIS, 5) unit (Cita et al. 2005). In fact, the presence of $P$. latus cannot be interpreted as a single bio-event but a consequence of global warming (Cornu et al. 1993; González-Delgado et al. 1998, 2000). To confirm this, we dated $P$. latus-bearing deposits through amino acid racemization on pelecypod shells and $U / T h$ on corals and rodoliths. Thus, beds bearing $P$. latus offer palaeoenvironmental evidence to be used as proxies of the effects of global warming. Because the measurements of amino acid content are obtained as a by-product of amino acid racemization analyses, in this study we also used the aspartic acid content as an indicator of the preservation of OMs, namely proteins, which control shell biomineralization.
Here, we present the geochemistry (organic and inorganic) of $P$. latus and the age of some Iberian Mediterranean deposits. In addition, in order to determine whether $P$. latus has mineralogical characteristics that could be restricted to the Mediterranean realm, we compared our results with those obtained in several other strombid species from other seas with distinct temperatures and salinities. These samples included some Atlantic and eastern Pacific species like $P$. latus, L. gigas, Lobatus raninus (Gmelin 1971) and Strombus alatus Gmelin 1791, all of which are linked to a relatively recent monophyletic radiation (Latiolais et al. 2006), and Indo-West Pacific representatives: Laevistrombus canarium (Linnaeus 1758), Tricornis latissimus (Linnaeus 1758) and Lentigo lentiginosus (Linnaeus 1758).

\section{Materials and methods}

Samples of extant $P$. latus shells were obtained from the Instituto Nacional de Desenvolvimento das Pesquerias (INDP) and from fisheries in Cabo Verde and Senegal. Samples of L. gigas were obtained directly from fishermen on the Island of Santo Domingo. Finally, shells of other species were purchased from shell dealers. Hundreds of fossil P. latus samples were recovered in various Mediterranean localities in Spain (Fig. 1; Table 1).

Strata bearing $P$. latus are usually strongly carbonate cemented and wave erosion occurs when these shells and rock are found in the current surf zone. Nevertheless, in the area of Roquetas de Mar, where beach resorts are built on gravels and sands from an ancient foreshore prograding beach up to $3 \mathrm{~m}$ above the sea level, there is a marked absence of calcium carbonate cement and shell samples of the Senegalese Complex were easily retrieved by hand.

For amino acid racemization dating, Glycymeris Da Costa 1778 shells and in some cases also Arca noae Linnaeus 1758 representatives were recovered from the fossil $P$. latus-bearing deposits. For the U/Th dating of some sites, the coral Cladocora caespitosa (Linnaeus 1767) and rodoliths were recovered.

\section{Shell mineralogy}

Thin sections. - For mineralogical analyses, shells were sectioned with a Buehler variable speed saw equipped with a $0.5-\mathrm{mm}$ circular diamond wafering blade. The sections were polished using a Struers device. The cut direction was roughly perpendicular to the growth direction of the last whorl.

A total of 20 thin sections from the labrum were examined in extant representatives of seven species: 


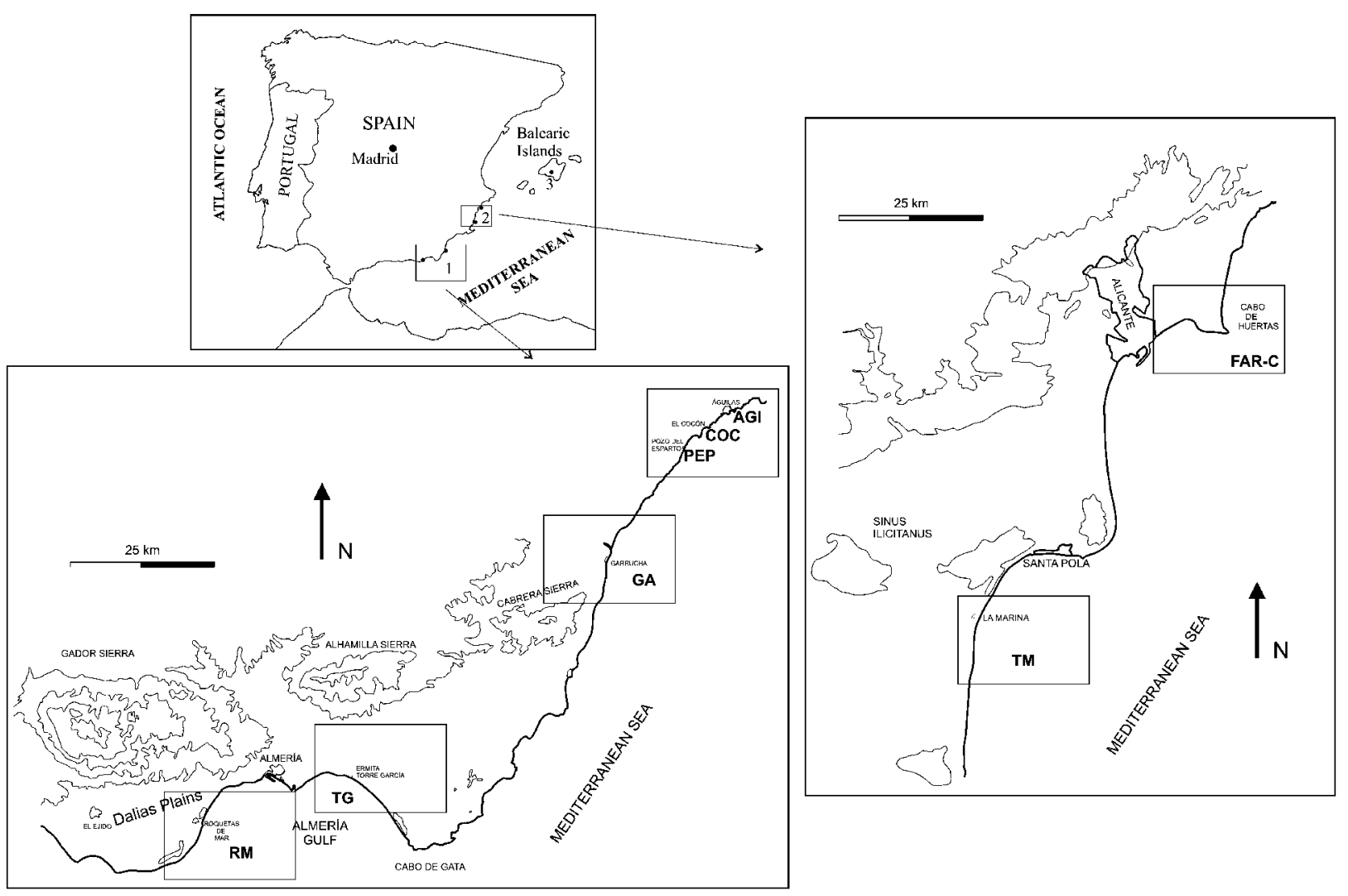

Fig. 1. Geographical location of the studied area and other sites that appear in this paper. Key: 1, Roquetas de Mar-RM, Torre García-TG, Garrucha-GA, Pozo del Esparto-PEP, Cocón Beach-COC, Águilas-AGI; 2, TM-Cantera de Pinet, Faro de Huertas-FAR; 3, Campo de Tiro, Son Grauet (Mallorca Island).

Table 1. Geographical location of the fossil P. latus bearing deposits on the Iberian Peninsula Mediterranean coast (Roquetas de Mar areaRM, Torre García-TG, Garrucha-GA, Pozo del Esparto-PEP, Cocón Beach-COC, Águilas-AGI, Cantera de Pinet-TM, Campo de Tiro-CTI, SGR-Son Grauet, FAR-Faro de Huertas) and abundance of the main mollusc species.

\begin{tabular}{|c|c|c|c|c|c|c|}
\hline Site & Latitude & Longitude & Elevation $(\mathrm{m})$ & Glycymeris sp. & Arca noae & P. latus \\
\hline RM-4 & $36^{\circ} 44^{\prime} 34^{\prime \prime} \mathrm{N}$ & $2^{\circ} 37^{\prime} 0^{\prime \prime} \mathrm{W}$ & 9.9 & $* * * *$ & * & $* * * *$ \\
\hline RM-5 & $36^{\circ} 45^{\prime} 10^{\prime \prime} \mathrm{N}$ & $2^{\circ} 36^{\prime} 25^{\prime \prime} \mathrm{W}$ & 7.6 & $* * * *$ & * & $* * * *$ \\
\hline RM-6 & $36^{\circ} 45^{\prime} 24^{\prime \prime} \mathrm{N}$ & $2^{\circ} 36^{\prime} 26^{\prime \prime} \mathrm{W}$ & 6.5 & $* * * *$ & * & $* * * *$ \\
\hline RM-8 & $36^{\circ} 45^{\prime} 9^{\prime \prime} \mathrm{N}$ & $2^{\circ} 36^{\prime} 25^{\prime \prime} \mathrm{W}$ & 7.5 & $* * * *$ & * & $* * * *$ \\
\hline RM-9 & $36^{\circ} 44^{\prime} 44^{\prime \prime} \mathrm{N}$ & $2^{\circ} 36^{\prime} 48^{\prime \prime} \mathrm{W}$ & 3.5 & $* * * *$ & * & $* * * *$ \\
\hline RM-11 & $36^{\circ} 44^{\prime} 9^{\prime \prime} \mathrm{N}$ & $2^{\circ} 37^{\prime} 19^{\prime \prime} \mathrm{W}$ & 8.0 & - & * & $* * * *$ \\
\hline $\mathrm{TG}$ & $36^{\circ} 49^{\prime} 25^{\prime \prime} \mathrm{N}$ & $2^{\circ} 17^{\prime} 41^{\prime \prime} \mathrm{W}$ & 4.0 & $* * * *$ & * & $* * *$ \\
\hline GA-3 & $37^{\circ} 28^{\prime} 35^{\prime \prime} \mathrm{N}$ & $1^{\circ} 48^{\prime} 33^{\prime \prime} \mathrm{W}$ & 3.5 & $*$ & * & * \\
\hline GA-10 & $37^{\circ} 6^{\prime} 58^{\prime \prime} \mathrm{N}$ & $1^{\circ} 50^{\prime} 14^{\prime \prime} \mathrm{W}$ & 3.5 & $* *$ & * & * \\
\hline GA-11 & $37^{\circ} 6^{\prime} 23^{\prime \prime} \mathrm{N}$ & $2^{\circ} 49^{\prime} 52^{\prime \prime} \mathrm{W}$ & 3.5 & $* *$ & * & * \\
\hline GA-12 & $37^{\circ} 7^{\prime} 35^{\prime \prime} \mathrm{N}$ & $1^{\circ} 49^{\prime} 45^{\prime \prime} \mathrm{W}$ & 5.0 & $* * * *$ & * & $* *$ \\
\hline GA-15 & $37^{\circ} 12^{\prime} 44^{\prime \prime} \mathrm{N}$ & $2^{\circ} 48^{\prime} 31^{\prime \prime} \mathrm{W}$ & 5.0 & $* * * *$ & - & $* *$ \\
\hline GA-14-1 & $37^{\circ} 10^{\prime} 20^{\prime \prime} \mathrm{N}$ & $1^{\circ} 49^{\prime} 18^{\prime \prime} \mathrm{W}$ & 3.5 & $* * *$ & * & $* * *$ \\
\hline PEP & $37^{\circ} 19^{\prime} 55^{\prime \prime} \mathrm{N}$ & $1^{\circ} 41^{\prime} 37^{\prime \prime} \mathrm{W}$ & 0.5 & - & $* * * *$ & $* *$ \\
\hline $\mathrm{COC}$ & $37^{\circ} 23^{\prime} 20^{\prime \prime} \mathrm{N}$ & $2^{\circ} 36^{\prime} 38^{\prime \prime} \mathrm{W}$ & 1.1 & - & - & $* * *$ \\
\hline AGI & $37^{\circ} 23^{\prime} 34^{\prime \prime} \mathrm{N}$ & $2^{\circ} 36^{\prime} 21^{\prime \prime} \mathrm{W}$ & $0-2$ & * & - & $* * * *$ \\
\hline TM1 & $38^{\circ} 9^{\prime} 59^{\prime \prime} \mathrm{N}$ & $0^{\circ} 37^{\prime} 49^{\prime \prime} \mathrm{W}$ & 5 & - & $* *$ & $* *$ \\
\hline TM4 & $37^{\circ} 58^{\prime} 38^{\prime \prime} \mathrm{N}$ & $0^{\circ} 38^{\prime} 11^{\prime \prime} \mathrm{W}$ & 5.0 & $* *$ & $* *$ & $* * * *$ \\
\hline FAR-C & $38^{\circ} 21^{\prime} 15^{\prime \prime} \mathrm{N}$ & $0^{\circ} 24^{\prime} 14^{\prime \prime} \mathrm{W}$ & 2.0 & $* * * *$ & $*$ & $* * *$ \\
\hline SGR & $39^{\circ} 29^{\prime} 56^{\prime \prime} \mathrm{N}$ & $2^{\circ} 44^{\prime} 52^{\prime \prime} \mathrm{E}$ & 0.5 & $* *$ & - & * \\
\hline CTI & $39^{\circ} 32^{\prime} 39^{\prime \prime} \mathrm{N}$ & $2^{\circ} 42^{\prime} 25^{\prime \prime} \mathrm{E}$ & 1.0 & $* *$ & * & * \\
\hline
\end{tabular}

The presence of the different species is marked with *.

L. lentiginosus, P. latus, L. gigas, S. alatus, L. raninus, L. canarium and T. latissimus, and from several parts of the shell for fossil P. latus individuals, in order to compare the mineralogy of present-day and fossil species. The fossil $P$. latus samples examined corresponded to the labrum of the shell (SB-1), the ventral 
part of the last whorl (SB-2 and SB-3) and the columella (SB-4).

For mineralogical and OM distribution, the thin sections were stained. To distinguish between the two calcium carbonate polymorphs that are usually the mineral constituents of mollusc shells, we applied Feigl's solution, which was prepared following Feigl (1937, in Friedman 1959)). This procedure stained aragonite crystals black, while calcite ones remain unstained.

To highlight the organization of the OM and the crystal arrangement, we used Mutvei's solution (Mutvei et al. 1994), following the modifications described by Schöne et al. (2005). This solution stains mucopolysaccharides by etching mineral structures. The use of the Mutvei's solution facilitates the identification of micro-growth structures in carbonates of biogenic origin by staining OM laminae and crystal envelopes in shades of blue. The biogenic carbonate was identified under a microscope using plain light.

These sections were also studied under reflected light with a binocular Leica DMLP microscope equipped with a Nikon Coolpix 4500 digital camera. Later, several sections were examined using a scanning electron microscope (SEM) Geol $6100(0.3-30 \mathrm{kV}$ and $4 \mathrm{~nm}$ of theoretical resolution) with secondary and retrodispersed electrons with micro-analysis XR Edax (Technical Services of the University of Oviedo) and a Quanta 200 (Oxford), under vacuum mode (National Museum of Natural History, CSIC, Madrid).

$X$-ray analysis. - For X-ray analyses, we used samples from representatives of the six extant species (L. lentiginosus, P. latus, L. gigas, S. alatus, L. raninus and $L$. canarium) and the fossil P. latus. Slices from the labrum were cut off and the small blocks obtained were ground in an agate mortar. Given that sponge borings can affect the original mineralogy (cf. Rehman et al. 1994), we selected only non-bioeroded shells. For analytical purposes, we used the crystalline powder method in a XPERT PRO from Panalytical, with a copper tube, a graphite monocromer and automatic aperture (PTE-RX-004). The software High Score (Panalytical) and ICDD Database (Instituto Geológico y Minero de España) were used. Semi-quantitative values were obtained through the reflective power described by Schultz (1964): 0.33 for aragonite and 1.00 for calcite at 3.40 and $3.03 \AA$ respectively.

\section{Carbon and oxygen stable isotope analysis}

To study the growth of strombid shells, we performed stable isotopic analysis. Twenty-two samples of a single fossil $P$. latus shell from the locality named RM-4
(Fig. 1) were obtained by drilling the whorl in the growth direction with a 3-mm-diameter steel drill. Following the method proposed by Wefer \& Killingley (1980), eight more samples were scraped from visible stacked shell layers of the labrum. For comparative purposes and following the same ontogenetic sampling, we obtained 16 samples from a juvenile fossil $P$. latus, which was recovered from the same bed as the adult shell in RM-4, and 37 samples from an adult extant $P$. latus shell from Cabo Verde, two of the samples being from the labrum. Stable isotope determinations were made at the Estación Experimental El Zaidin (CSIC, Granada). The procedure was as follows: the sample was crushed and heated at $400^{\circ} \mathrm{C}$ under nitrogen atmosphere for $1 \mathrm{~h}$ to remove organic matter. Carbon dioxide was evolved using $100 \%$ phosphoric acid for $30 \mathrm{~min}$ in a thermostatic bath at $80^{\circ} \mathrm{C}$ (McCrea 1950; Swart et al. 1991). A pyrex microline was used for gas purification and oxygen stable isotope analyses were conducted in a Finnigan MAT 251 mass spectrometer. Results are reported in standard $(\delta)$ notation in parts per thousand $(\%)$ relative to the international V-PDB standard (Gonfiantini 1981). All the samples were compared with a reference carbon dioxide standard. The experimental error was less than $\pm 1 \%$. Carrara and EEZ-1, which had previously been compared with the international standards NBS-18 and NBS-19, were used as internal standards.

\section{Organic matrix preservation}

The preservation of the OM was evaluated by measuring the aspartic acid content in 153 fossil P. latus representatives recovered in the localities shown in Table 1 and by comparing these results with those (12) for extant individuals of other species ( $P$. latus, L. lentiginosus, L. gigas, S. alatus, L. raninus and L. canarium).

A 25-mm-diameter discoid sample was drilled in the ventral side of the last whorl of the shells using a hollow diamond drill. Peripheral parts with visible weathering, approximately $20-30 \%$, were removed after chemical etching with $2 \mathrm{~N} \mathrm{HCl}$. Afterwards, $80 \mathrm{mg}$ of sample was taken.

The amino acid racemization analyses were performed in the Biomolecular Stratigraphy Laboratory following the sample preparation protocol described in Goodfriend (1991) and Goodfriend \& Meyer (1991). Samples were analysed in a HP 5890 gas chromatograph with an NPD detector and a Chirasil-L-Val-fused silica column. The chromatographic conditions are described in detail in Ortiz et al. (2004a). Aspartic acid abundance was estimated through the sum of the peak areas of the D and L enantiomers. 
To validate our gas chromatography results, we also analysed samples from Wehmiller's (1984) Inter-Laboratory Comparison (ILC) exercise (Torres et al. 1997, 2000).

\section{Chronology}

To calculate the age of $P$. latus beds, we used mostly the amino acid racemization ratios of Glycymeris sp. shells recovered in the same levels and, in three localities, we applied the U/Th dating method on corals and rodoliths.

Amino acid racemization. - The age of the P. latusbearing localities was established using the amino acid racemization ratios of individuals of Glycymeris. This genus was selected because it is the most common and abundant in almost all raised coastal marine deposits in the Mediterranean region. In addition, the dating calculation algorithms, which allow the transformation of $D / L$ ratios into age, were previously established for this genus (Ortiz et al. 2004b). In some localities (TG and PEP) it was impossible to find Glycymeris sp. shells for amino acid racemization dating, and Arca noae individuals were therefore selected to convert their $D / L$ ratios into Glycymeris equivalent ones, following Hearty (1987). Only in a few localities (RM11, COC, AGI, GA-11 and TM-4) were Glycymeris and Arca shells absent and thus we were unable to date these deposits. The number of samples from each locality is shown in Table 2. For the amino acid racemization, a hollow diamond drill was used to remove a discoid sample (8 $\mathrm{mm}$ in diameter) from an area as close as possible to the beak of the shells. The sample preparation protocol and chromatographic conditions were as indicated above. On the basis of amino acid racemization of Glycymeris sp. shells established by Ortiz et al. (2004b), D/L ratios were introduced in the age calculation algorithms. These algorithms were calibrated through radiometric dating of shells $\left({ }^{14} \mathrm{C}\right)$ and corals $(\mathrm{U} / \mathrm{Th})$ and we also added the results on the $\mathrm{U} / \mathrm{Th}$ dating of rodoliths.

$U / T h$ dating. - For U/Th dating, four samples consisting of the coral C. caespitosa were collected from FAR-C (Faro de Huertas area, Fig. 1). In addition, algal rodoliths were recovered at two sites: four samples from RM-4 and three samples from RM-9. We did not use mollusc shells for U/Th dating because they are not suitable (Kaufman et al. 1971, 1996). Although several authors have suggested that mollusc shells show early uranium uptake (Broecker 1963; Ivanovicht et al. 1983), it has been proved that in vivo they incorporate very small amounts of this element, whereas the bulk of their uranium content is mostly diagenetic in origin. In fact, mollusc fossil shells have about eight times as much uranium and considerably higher ${ }^{234} \mathrm{U} /{ }^{238} \mathrm{U}$ than the shells of living gastropods (Kaufman et al. 1996). Uranium uptake occurs in the first 15 kyr after death; there is also a considerable variation in uranium distribution in the shell. Nevertheless, consistent results were obtained in Holocene deposits from the Canary Islands (Hillaire-Marcel et al. 1995) and in Pleistocene marine terraces in the Balearic Islands (Hillaire-Marcel et al. 1996). Corals take up uranium during their vital cycle (Stein et al.

Table 2. Amino acid racemization/epimerization ratios measured in Glycymeris shells from the different localities and corresponding age.

\begin{tabular}{|c|c|c|c|c|c|c|}
\hline Site & $\mathrm{N}$ & D-aIle/L-Ile & $D / L$ Asp & $D / L$ Phe & $D / L$ Glu & Age (ka) \\
\hline RM-4 & 26 & $0.648 \pm 0.077$ & $0.729 \pm 0.060$ & $0.693 \pm 0.066$ & $0.574 \pm 0.051$ & $181 \pm 47$ \\
\hline RM-5 & 7 & $0.701 \pm 0.039$ & $0.750 \pm 0.061$ & $0.693 \pm 0.052$ & $0.560 \pm 0.054$ & $198 \pm 44$ \\
\hline RM-6 & 7 & $0.698 \pm 0.078$ & $0.773 \pm 0.038$ & $0.704 \pm 0.058$ & $0.572 \pm 0.059$ & $200 \pm 52$ \\
\hline RM-8 & 6 & $0.680 \pm 0.048$ & $0.746 \pm 0.049$ & $0.717 \pm 0.018$ & $0.544 \pm 0.045$ & $209 \pm 50$ \\
\hline RM-9 & 10 & $0.687 \pm 0.062$ & $0.757 \pm 0.039$ & $0.657 \pm 0.050$ & $0.554 \pm 0.047$ & $192 \pm 35$ \\
\hline $\mathrm{TG}$ & 6 & $0.709 \pm 0.065$ & $0.698 \pm 0.038$ & $0.665 \pm 0.078$ & $0.554 \pm 0.026$ & $165 \pm 59$ \\
\hline GA-3 & 10 & $0.640 \pm 0.062$ & $0.757 \pm 0.033$ & $0.667 \pm 0.043$ & $0.566 \pm 0.042$ & $162 \pm 34$ \\
\hline GA-10 & 2 & $0.520 \pm 0.010$ & $0.776 \pm 0.005$ & $0.686 \pm 0.009$ & $0.546 \pm 0.004$ & $152 \pm 44$ \\
\hline GA-12 & 8 & $0.463 \pm 0.038$ & $0.772 \pm 0.034$ & $0.710 \pm 0.017$ & $0.577 \pm 0.025$ & $190 \pm 41$ \\
\hline GA-14-1 & 10 & $0.559 \pm 0.021$ & $0.739 \pm 0.023$ & $0.653 \pm 0.044$ & $0.564 \pm 0.025$ & $145 \pm 24$ \\
\hline GA-15 & 17 & $0.524 \pm 0.026$ & $0.706 \pm 0.051$ & $0.625 \pm 0.057$ & $0.506 \pm 0.042$ & $119 \pm 34$ \\
\hline PEP & 4 & $0.516 \pm 0.027[0.682 \pm 0.036]$ & & & & $191 \pm 22$ \\
\hline FAR-C & 15 & $0.527 \pm 0.081$ & $0.570 \pm 0.080$ & $0.516 \pm 0.073$ & $0.472 \pm 0.063$ & $128 \pm 36$ \\
\hline TM1 & 2 & $0.351 \pm 0.024[0.436 \pm 0.032]$ & & & & $80 \pm 12$ \\
\hline SGR & 6 & $0.500 \pm 0.014$ & $0.685 \pm 0.052$ & $0.603 \pm 0.043$ & $0.506 \pm 0.055$ & $109 \pm 29$ \\
\hline CTI-2 & 4 & $0.503 \pm 0.040$ & $0.674 \pm 0.015$ & $0.536 \pm 0.011$ & $0.522 \pm 0.016$ & $99 \pm 12$ \\
\hline CTI-3 & 4 & $0.501 \pm 0.022$ & $0.684 \pm 0.004$ & $0.562 \pm 0.029$ & $0.532 \pm 0.031$ & $102 \pm 18$ \\
\hline CTI-4 & 6 & $0.486 \pm 0.019$ & $0.690 \pm 0.031$ & $0.566 \pm 0.044$ & $0.515 \pm 0.025$ & $107 \pm 17$ \\
\hline
\end{tabular}

In PEP and TG, D-alle/L-Ile ratios were obtained in Arca noae specimens. They were converted into Glycymeris D-alle/L-Ile values (put into brackets) using a Glycymeris/Arca ratio of 1.32 (Hearty 1987). $n$ is the number of samples analysed. D-alle/L-Ile, D-alloisoleucine/ $\mathrm{L}-\mathrm{isoleu}$ cine; Asp, aspartic acid; Phe, phenylalanine; Glu, glutamic acid. 
1991, 1993); however, unfortunately, corals are found in only a few localities (Zazo et al. 2003; Ortiz et al. 2004b).

Our U/Th analyses were performed at the Instituto Jaume Almera (CSIC, Barcelona). The procedure used for chemical preparation was based on that developed by Bischoff \& Fitzpatrick (1991). The sample was totally dissolved in strong mineral acids and a radioisotope with known activity was introduced to determine the efficiency of the isotope separation. The $\mathrm{U}$ and Th isotopes were isolated by ion-exchange chromatography and then analysed in an alpha spectrometer from Ortec with a silica barrier detector. For age calculation, the UDATE program by Rosenbauer (1991) was used.

\section{Results and discussion}

\section{Shell mineralogy: thin sections}

In some experiments of calcium carbonate in vitro crystallization, other polymorphs were obtained (Becker et al. 2003) with a higher OM content. In a muricid shell [Concholepas concholepas (Bruguière 1789)] the organic matter content of the outer calcitic layer is higher than in the lamellar layer (Dauphin et al. 2003). Samata $(1990,2004)$ demonstrated that the organic matter composition (amino acid content) differs markedly among the three types of shell layer (nacreous and prismatic foliated, lamellar and complex layers).

Pokroy et al. (2006) extracted a $40-\mathrm{kDa}$ protein from the strombid Conomurex persicus (Swainson, 1821), which was used for in vitro crystallization experiments. With no added protein, calcite was formed but vaterite formed upon addition of protein. According to these authors, vaterite, a thermodynamically unstable polymorph, participates in the transformation of amorphous calcium carbonate into aragonite.

Our microscopic analysis of the macro-architecture of 20 full cross-sections from the labrum of seven species of strombid revealed marked differences between the internal shell crystalline arrangement in the labrum, whorls, apex and spines. Using Feigl's solution, which stains the surface of aragonite black while calcite remains unstained, we also observed the transformation of aragonite into calcite. In most of the section examined, it was possible to observe the partial, in situ transformation of aragonite into calcite, while the aragonite growth structure of the shell was usually preserved.

Our study confirms that the layers that make up the wall of the shell are formed by first-, second- and third-order lamellae. The latter are visible only at high magnification; so, they have been photographed in very few samples.

In several samples from extant species, we identified a very thin protein-rich periostracum and the replacement of aragonite by calcite in the shell. By contrast, the presence of calcite was greater in the fossil specimens. The layer of nacre, which is made up mostly of aragonite, was found only in some of the extant shells (P. latus), while this layer had recrystallized to calcite or disappeared in the fossil shells. In some extant representatives ( $P$. latus, $L$. raninus and $L$. lentiginosus), the inner layer of the shell was in contact with the nacre and consisted mostly of heterogeneous, crosscutting fibrous lamellae perpendicular to the shell surface, and the in situ replacement of aragonite by calcite resulted in the preservation of the prismatic, fibrous aragonite structure. The replacement of aragonite by calcite in all the thin sections studied was found to be more common between shell layers and in the lamellae, which were oriented parallel to the surface of the shell (Fig. 2A1, A2). Neither the nacre nor the periostracum was observed in the sample shown in Fig. 2A3.

The full cross-sections of extant and fossil shells (Fig. 2A2, A4) stained with Mutvei's solution show the growth layers of biogenic carbonate as bluish lines that separate the main shell layers and that are parallel to the outer part of the labrum. A simple, lamellar fibrous structure in which the fibres are oriented perpendicular to the surface of the shell was observed in the internal, intermediate and external layers (Fig. 2A4). Here, Mutvei's dye allowed us to distinguish two structures: one prismatic, fibrous and crosslamellar and occurring in the external layer of aragonite; the other fibrous, needle like and of variable thickness, occurring in the intermediate layers (Fig. 2A4). These observations indicate an irregular distribution of organic matter through the shell section. Mutvei's solution revealed rich-organic matter stripes parallel to the shell surface as well as OM envelopes enclosing aragonite crystals.

In a juvenile representative (Fig. 2A5), the internal layer comprised prisms arranged perpendicular to the shell dorsum surface. Mutvei's solution produced a strong stain in the most external zone, the general prism orientation changed towards the upper part of the layer and showed an almost regular thickness. A dark thin band marked a new accretion event made of crossed lamellae with a distinct orientation where at least four accretion bands of distinct thickness were distinguished. This layer, mostly the uppermost laminae, thickened markedly to start the spine build-up. The main contributor to spine elevation was a third layer, which showed the same crystal orientation as in the shell dorsum surface. 
A1

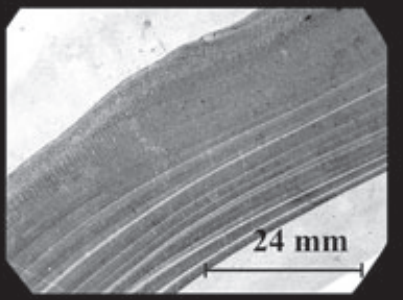

A2

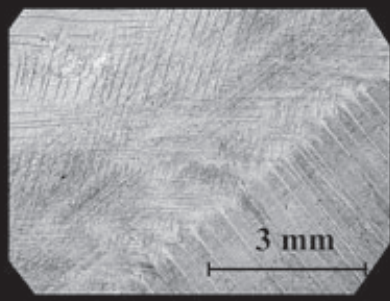

A3

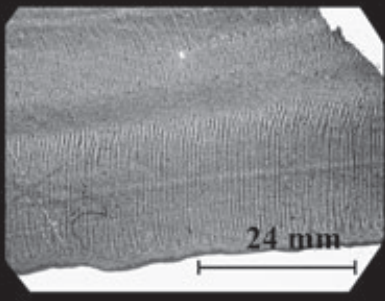

A4

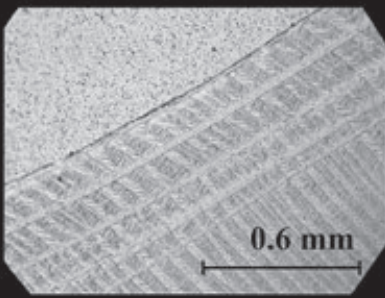

A5

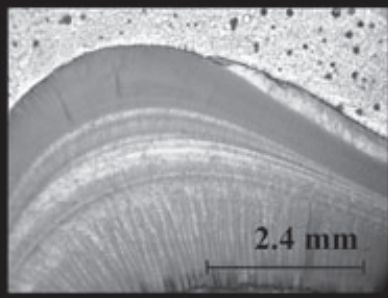

B1

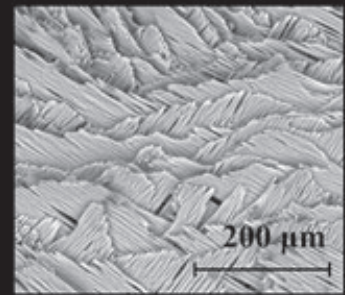

B2

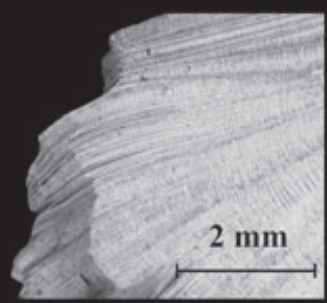

B3

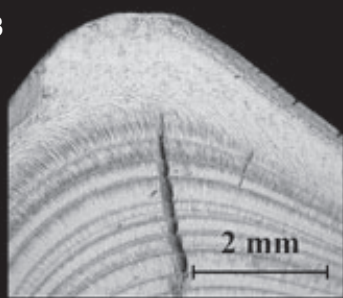

B4

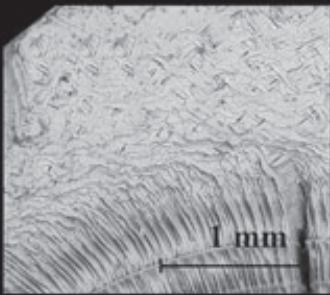

B5

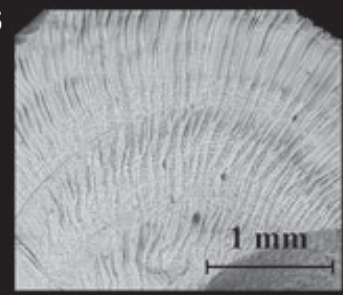

C1

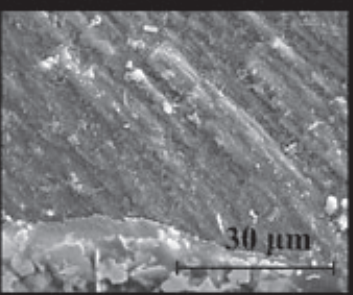

C2

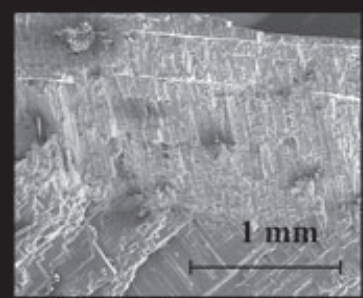

C)

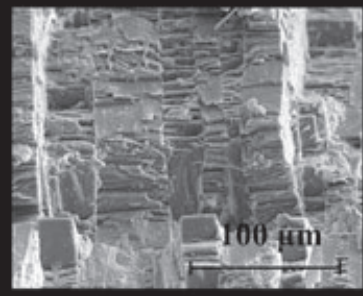

C4

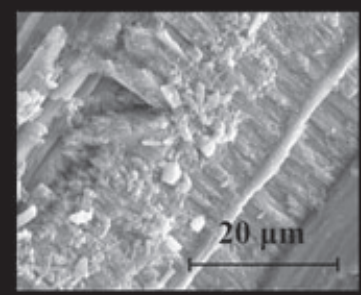

C5

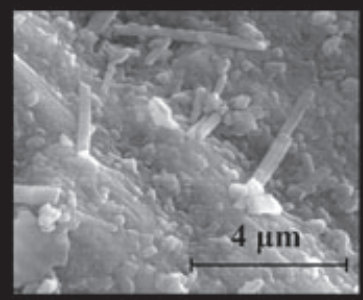

Fig. 2. Strombid shell ultrastructure of A1, A2, thin sections stained with Feigl's solution. A1, full section of Strombus alatus in which calcite laminae (unstained) are visible. A2, full section of fossil P. latus with the first- and second-order lamellae. A3, A4, thin sections stained with the Mutvei's solution. A3, external part of the shell of fossil P. latus, first- and second-order lamellae are observed surrounded by rich-organic matter in stripes parallel to the shell surface. A4 internal part of the shell of $S$. lentiginus with first- and second-order lamellae surrounded by rich organic matter stripes parallel to the shell surface. A5, thin section of the last whorl of a fossil juvenile P. latus, at the area of the last spine. $\mathrm{B} 1$, ventral part of the last whorls of $P$. latus, showing the cross-lamellar structure. B2 external part of the external labrum of fossil $P$. latus; a gradual wedging of the laminae is observed. B3, complete section of the last whorl of fossil $P$. latus corresponding to the most external spine, where 15 laminae of the intermediate layer are clearly observed; they are followed by external layer that clearly enlarges in the spine region. B4, boundary between the external and internal layers of fossil P. latus in which the cross-lamellar, fibrous-like structure of the intermediate layer passes gradually to the external laminae by a senestral, $90^{\circ}$ helical rotation. B5, detail of the columella in a juvenile specimen of fossil $P$. latus. C1, internal part of the shell of Lobatus gigas in which nacre, periostracum and first- and second-order lamellae and some of the thirdorder ones are observed. C2, external layers of extant P. latus with their respective first- and second-order lamellae. C3, internal part of the external layer of fossil P. latus showing first- and second-order lamellae. C4, intermediate layer of fossil P. latus of the ventral part of the last whorls, in which first- and second-order lamellae are observed. C5, second- and third-order lamellae of the internal part of the shell in $L$. gigas. 
It is noteworthy that the spine was flanked on both sides by an accretion layer made of crossed lamellae that had been abraded during shell transportation. In a sample of $L$. gigas, we also identified the organic matter as envelopes of the first-, second- and thirdorder lamellae and this matter was also found between the main shell layers.

Finally, thin full cross-sections of extant and fossil strombid shells were studied under a SEM. The samples from the extant shells were taken from the labrum, and those from the fossil $P$. latus corresponded to the external lip (labrum) of the shell (Fig. 2A2), the ventral part of the last whorls (Fig. 2C4) and the columella (Fig. 2B5). In the sections of the extant specimens, the various components of the shell were identified and photographed, including the nacre, periostracum and the various intermediate layers that form the shell itself. We also identified the proteinrich organic matter that covered the first-, secondand third-order lamellae and that was also found between the main shell layers (Fig. 2C1).The study of the thin sections under a SEM gave the following results.

Sample of Lobatus gigas. - We observed the alternating surfaces, smooth and rough in appearance, of first-order lamellae, which corresponded to prismatic, simple lamellar fibrous-like structures of the external layers and the cross, needle-like structures of the intermediate layers. Images of the acicular third-order lamellae of the internal layers were obtained (Fig. 2C1, C5).

Samples of extant Persististrombus latus and Strombus alatus. - In the most external parts of the shell, the intermediate layers increased in number and thickness, while they became thinner in the inner parts of the shell (Fig. 2C2).

Samples of fossil Persististrombus latus. - In one of the samples, which corresponded to the columella, it was difficult to identify laminae (Fig. 2B5). However, layers with needle-like, crossed lamellar structure, as well as first-, second- and even some of their thirdorder lamellae, were identified (Fig. 2C3, C4). Abatino et al. (1971) described similar structures. In the ventral part of the last whorl (Fig. 2B1), we observed three layers as well as the cross-lamellar, fibrous-like structure of the intermediate layer, which passed gradually to the external laminae by a senestral, $90^{\circ}$ helical rotation (Fig. 2B1).

In the external part of the labrum at least 15 laminae were identified. These showed the cross-needlelike structure characteristic of the intermediate layers. Moreover, a gradual wedging (stacking) towards the last whorls was detected in some inner laminae of the intermediate layers (Fig 2B2). Finally, in a full crosssection corresponding to the section of the higher spine on the body whorl, 15 laminae of the intermediate layer were clearly observed. They were followed by the external layer, which was clearly enlarged near the spine top and comprised mineral platelets, showing a gradual anti-clockwise, $90^{\circ}$ helicoidal rotation to its external layer (Fig. 2B3, B4).

For comparative purposes, we sectioned a juvenile representative of fossil $P$. latus from Roquetas de Mar (RM-4). This specimen presented the following characteristics: total length ca. $90 \mathrm{~mm}$, labrum undeveloped, and the broken end of the protolabrum ca. $1 \mathrm{~mm}$ in thickness. A thin section of the body whorl, including the last spine, showed simpler laminae stacking than adult specimens. The outer lamina had been wave abraded in the spine area.

\section{Shell mineralogy: $X$-ray analysis}

These analyses revealed calcite in extant and fossil strombids (Table 3). The highest calcite concentrations were in samples from the fossil $P$. latus but these did not differ greatly from those found in adult juvenile (on the basis of lip thickness) L. canarium representatives. The calcite concentration in S. alatus and $L$. gigas did not differ greatly from that of fossil $P$. latus. Calcite presence in fossil $P$. latus was higher than in extant $P$. latus individuals. However, noticeable amounts of calcite were present in all the samples examined. Figure 3 includes an X-ray analysis of a S. alatus sample. In fact, even in nacre, where aragonite is considered to be monomineral in composition (aragonite platelets), Nassif et al. (2005) cited continuous layers of amorphous $\mathrm{CaCO}_{3}$.

\section{Shell mineralogy: carbon and oxygen stable isotopes}

The $\delta^{13} \mathrm{C}$ values in the adult fossil $P$. latus shell obtained following an ontogenetic transect, including the samples recovered from the labrum, ranged

Table 3. Percentage of calcite and aragonite in extant and fossil strombids using $\mathrm{X}$-ray analysis.

\begin{tabular}{lll}
\hline Species & \% Aragonite & \% Calcite \\
\hline Strombus alatus & 83 & 17 \\
Persististrombus latus (fossil) & 77 & 23 \\
Laevistrombus canarium & 80 & 20 \\
Lobatus gigas & 83 & 17 \\
Persististrombus latus (extant) & 86 & 14 \\
Lentigo lentiginostus & 85 & 15 \\
Strombus raninus & 84 & 16 \\
\hline
\end{tabular}




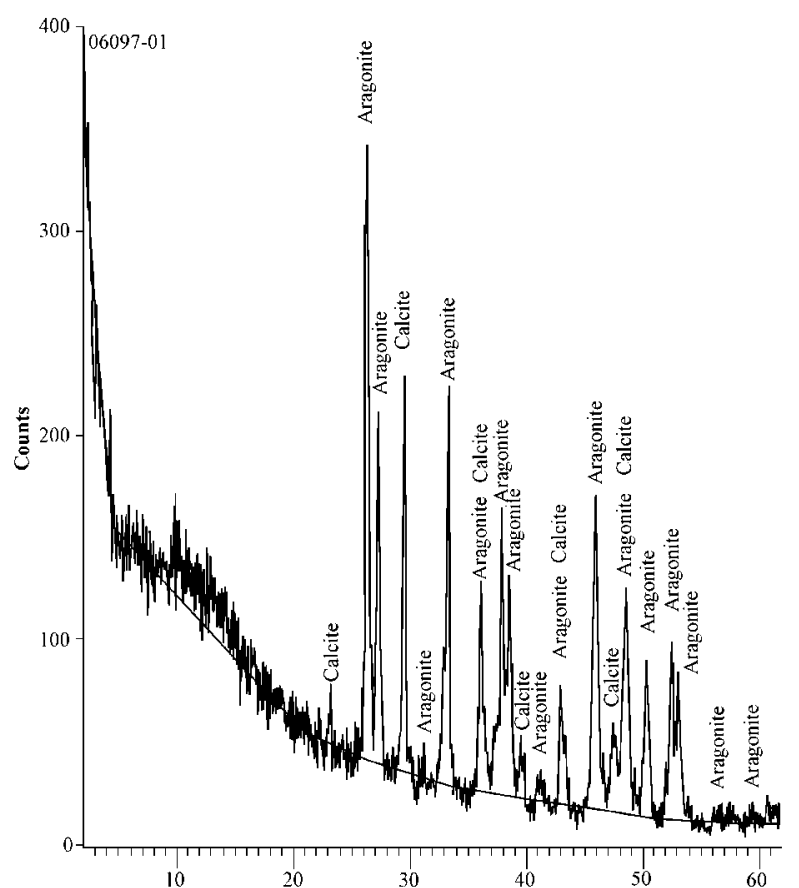

Fig. 3. X-ray diffraction analysis of a powdered sample from a Laevistrombus canarium shell.

between $-0.94 \%$ and $2.53 \%(\mathrm{~V}-\mathrm{PDB})$ and the $\delta^{18} \mathrm{O}$ values from $-3.04 \%$ to $0.18 \%$ (V-PDB). The $\delta^{13} \mathrm{C}$ values of the juvenile fossil $P$. latus representative showed a lower range, which varied between $-0.94 \%$ and $1.28 \%$ (V-PDB), and for $\delta^{18} \mathrm{O}$ values from $-1.59 \%$ to $0.67 \%$ (V-PDB). For the adult extant $P$. latus shell even fewer variations were observed, i.e. the $\delta^{13} \mathrm{C}$ values fell between $-2.06 \%$ and $-0.22 \%$ (V$\mathrm{PDB})$ and the $\delta^{18} \mathrm{O}$ ranged from $-0.85 \%$ to $0.41 \%$ (V-PDB).

The $\delta^{18} \mathrm{O}$ profiles following the spiral in the direction of growth of these three individuals are shown in Figure 4. For comparison, we adjusted the three lines to a standard length comprised between the first sample, taken at the protoconch, and the last sample obtained on the spire region. Thus, the samples drilled in the shell lip (extant P. latus) or taken as slices from the sectioned 8.3-mm-thick labrum of the adult fossil $P$. latus representative appear separately on the righthand side of the figure.

The lack of isotope signal shift toward positive values of the $\delta^{18} \mathrm{O}$ allows us to discard calcite presence being associated with meteoric water diagenesis. Our $\delta^{18} \mathrm{O}$ values matched those commonly observed in marine mollusca (Milliman 1974). Likewise, ranges as broad as those obtained for the $\delta^{18} \mathrm{O}$ values of the adult fossil $P$. latus representative have also been reported in fossil $P$. latus shells recovered in Mediterranean coastal-raised deposits in Spain (Cornu et al. 1993; González-Delgado et al. 2000) and from deposits in the Canary Islands (González-Delgado et al. 1998). However, we observed that the $\delta^{18} \mathrm{O}$ range of values in the extant $P$. latus representatives were less pronounced, which is consistent with the findings by Cornu et al. (1993) and González-Delgado et al. (1998).

It is observed that extant and fossil P. latus representatives showed a sawtooth pattern (Fig. 4), the maximum values of which are assumed to be produced during summer and minimum ones during winter (Cornu et al. 1993). Therefore, the age of a shell can be estimated assuming that each maximum and minimum represents a 6 -month time series. Thus, on the basis of the $\delta^{18} \mathrm{O}$ profiles (Fig. 4), we estimated the age of the fossil $P$. latus adult and juvenile representative to be 6 and 1.5 years respectively. These estimations are consistent with those reported by Cornu et al. (1993) and González-Delgado et al. (1998) in fossil $P$. latus shells, in which maturity was reached in 3-4 years. It is noteworthy that the labrum samples from the adult fossil P. latus individual represented a

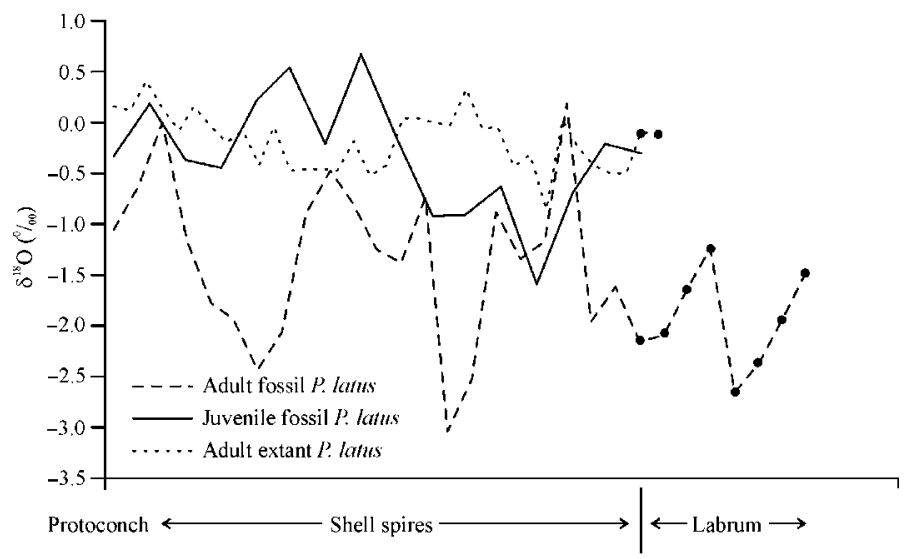

Fig. 4. Oxygen stable isotope profiles following the spiral in the direction of growth (from protoconch to labrum) in an adult and a juvenile fossil Persististrombus latus and an adult extant $P$. latus. 
2-year interval. However, the few variations detected in $\delta^{18} \mathrm{O}$ in extant $P$. latus from Cabo Verde do not allow us to interpret the true extent of its maturity onset, which we consider is probably around 6 years.

In some studies, $\delta^{18} \mathrm{O}$ values have been associated with seawater salinity and seasonal changes in temperature. In our case, the first $\delta^{18} \mathrm{O}$ values from the ontogenetic sampling, which included the protoconch and the very small first whorls, were almost identical for the samples, suggesting that seawater characteristics did not make a significant contribution during the initial growth stages. These values then markedly diverged, being more negative in the adult fossil $P$. latus samples.

Using $\delta^{18} \mathrm{O}$ values, Epstein \& Lowenstam (1953) calculated the growth rate and seawater temperature in L. gigas and S. costatus Gmelin 1791. Similarly, Cornu et al. (1993) and González-Delgado et al. $(1998,2000)$ interpreted the same from $\delta^{18} \mathrm{O}$ values measured in fossil $P$. latus from the Mediterranean and the Canary Islands. These authors did not sample the shell labrum.

Considering a lack of salinity change, Cornu et al. (1993) interpreted a $7^{\circ} \mathrm{C}$ increase in sea water for Monastir (Tunisia) and the Island of Majorca over the values registered today. If large salinity variations are considered, then the temperature difference can be reduced to $3^{\circ} \mathrm{C}$. These authors included relevant information about $\delta^{18} \mathrm{O}$ values in samples from living specimens of extant P. latus from the Gulf of Guinea as well as fossil $P$. latus from the Island of Majorca (Spain) and Monastir (Tunisia). It is of interest to note that isotopic values from extant $P$. latus shells showed fewer oscillations than the fossil P. latus. We observed that the isotopic values for one extant $P$. $l a-$ tus representative markedly differed from the other three examined, for which almost all the $\delta^{18} \mathrm{O}$ values fell between $-2.25 \%$ and $-1.75 \%$ (V-PDB), while the fourth was higher. The $\delta^{18} \mathrm{O}$ for fossil P. latus samples showed a marked sawtooth distribution, ranging between $-3.0 \%$ and $0.5 \%$ (V-PDB).

González-Delgado et al. (2000), in their studies of the average $\delta^{18} \mathrm{O}$ values in two fossil P. latus shells from two distinct strata of the same locality, concluded the occurrence of two highstand periods. However, given that a single fossil $P$. latus shell records a 4- to 6-year period, minor decadal or multi-decadal climate variations would be recorded in shells that, from a geochronological scale, can be considered coeval. In fact, Kowalewski et al. (1998) and Kowalewski \& Bambach (2003), analysing time averaging, concluded that in marine environments it is impossible to discriminate time periods shorter than 1000 years in which short-term climate oscillation occurred. In our view, the progressive shell thickening after the maturity onset of the shell makes it necessary to explore the possible bias of the isotopic signal (mostly in the last whorl) and further work in this direction is required.

\section{Organic matrix preservation}

Many proteins have been identified in several mollusc shells (Miyamoto et al. 1996; Shen et al. 1997; Sudo et al. 1997; Marin et al. 2000, 2005). Some of these proteins regulate $\mathrm{CaCO}_{3}$ polymorph determination (Belcher et al. 1996; Falini et al. 2000; Thomson et al. 2000; Kai et al. 2002; Tong et al. 2003) and are rich in acidic amino acids (Weiner \& Hood 1975; Weiner 1979).

There is a general consensus that aspartic acid plays a major role in mollusc biomineralization because of its capacity to nucleate calcite (Sarashina \& Endo 2001). In fact, 'the regular spacing of carboxyl side chains of Asp is a close match to that of $\mathrm{Ca}^{2+}$ in $\mathrm{CaCO}_{3}$ lattices and therefore controls the crystal polymorphism' (Samata 2004, p. 36). Therefore, it is plausible that the aspartic acid concentration is an indicator of OM preservation in P. latus.

Given the sample preparation method, we used for amino acid racemization dating of $P$. latus samples, the amino acid concentrations measured are the total amino acids from water-soluble and -insoluble fractions. In Figure 5, which shows $D / L$ Asp ratios against aspartic acid $(D+L)$ abundance, it is possible to observe two clusters. All P. latus samples group between 0.80 and $0.95 \mathrm{D} / \mathrm{L}$ Asp values, while samples from current species ( $S$. alatus, L. gigas, L. lentiginus, $L$. raninus, $L$. canarium, $T$. latissimus and $P$. latus) cluster around very low $D / L$ Asp ratios (0.03). The higher $D / L$ values registered for the P. latus samples can be explained by time- (and temperature-) controlled racemization. In fact, on the basis of the results presented below, the $P$. latus-bearing deposits belong to either MIS 7 or 5. The low, but measurable, $D / L$ Asp ratios for current species are due to the racemization induced by the sample preparation protocol (hydrolysis at $105^{\circ} \mathrm{C}$ for $24 \mathrm{~h}$ ).

It is of note that the abundance of aspartic acid of many fossil $P$. latus samples did not differ greatly from that of extant strombid representatives: at least $60 \%$ of the samples showed equivalent contents. The lower content can be explained by the effects of weathering. However, sample location (deeply buried, near surface or at the surf zone) did not play a decisive role in OM preservation of the thick $P$. latus shells. Burial depth effect is extremely relevant to the thinner Glycymeris sp. shells as it causes a marked scattering of racemization ratios (Torres et al. 2000). 


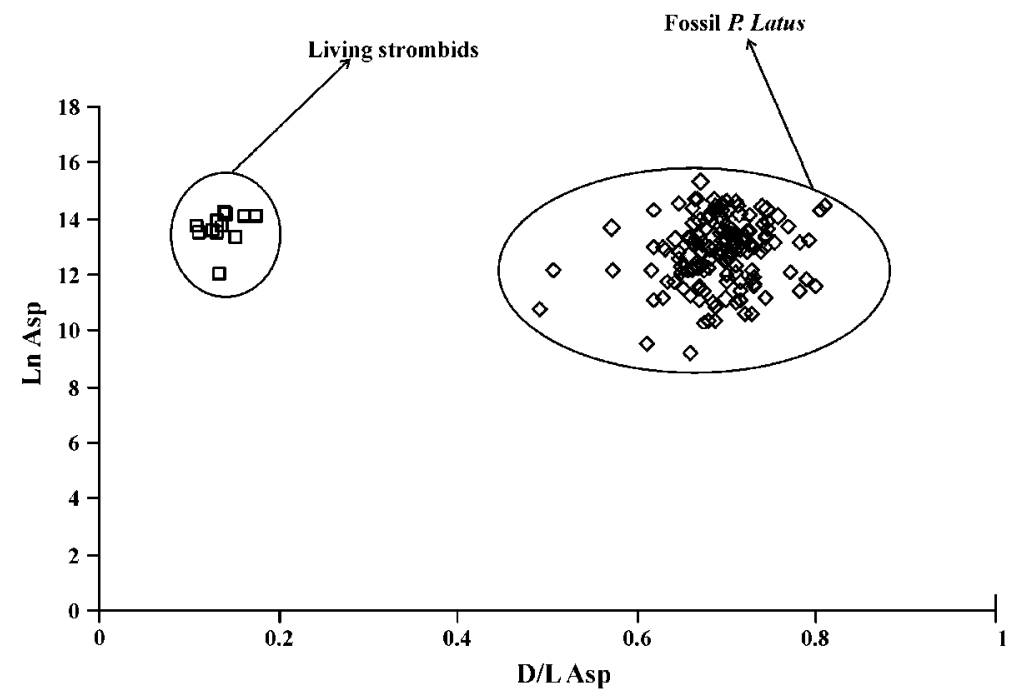

Fig. 5. $D / L$ Asp ratios against aspartic acid $(D+L)$ abundance in extant and fossil strombids. The extant representatives include Lentigo lentiginosus, Persististrombus latus, Lobatus gigas, Strombus alatus, raninusraninus and Laevistrombus canarium and are represented as circles, while fossil $P$. latus samples appear as squares.

\section{Chronology}

The mean $D / L$ ratios of four amino acids (isoleucine, aspartic acid, phenylalanine and glutamic acid) in Glycymeris shells are given in Table 2 . Leucine $D / L$ ratios are not shown because in many analyses spurious peaks appeared at the retention time of D-leucine, thereby producing bizarre $D / L$ values.

Thus, numerical datings of the $P$. latus localities were obtained by introducing the racemization/epimerization ratios of each amino acid of Glycymeris shells for each locality sampled into the age calculation algorithms (Table 2). The age uncertainty is the standard deviation of all the numerical ages (values) calculated from the amino acid $D / L$ ratios.

In samples from two localities (TG and PEP), Dalle/L-Ile ratios were obtained from Arca noae individuals and were converted into Glycymeris D-alle/L-Ile values using a Glycymeris/Arca ratio of 1.32 (cf. Hearty 1987). Unfortunately, in the localities named RM-11, COC, AGI, GA-11 and TM4, we were unable to recover Glycymeris or Arca shells, so we could not date them. Dating by Campo de Tiro and Son Grauet, both on the Island of Majorca, coincide with the ages reported by Hearty (1987) in the same localities.

Likewise, some U/Th dates were obtained (Table 4). Only one sample (RM-4(3)) provided ${ }^{230} \mathrm{Th}^{232} \mathrm{Th}$ ratios lower than 20 , thereby indicating post-depositional contamination or a significant input of detrital thorium (Schwarcz 1980; Ford \& Schwarcz 1981; Bischoff et al. 1994; Horvatinčić et al. 2000; Auler \& Smart 2001). In the FAR-C(4) sample, a ${ }^{230} \mathrm{Th} /{ }^{232} \mathrm{Th}$ ratio of 21.7 may point to contamination, but age results are consistent with those from the other samples of the RM-4 locality.
Table 4. U/Th datings in rodoliths and corals from Faro de Huertas (FAR-C) and Roquetas de Mar stations RM-4 and RM-9.

\begin{tabular}{llcl}
\hline Station & $\mathrm{Th}^{230} / \mathrm{U}^{234}$ & $\mathrm{Th}^{230} / \mathrm{Th}^{232}$ & Age (years) \\
\hline FAR-C (1) & 0.69 & $>100$ & $118985+4209 /-4059$ \\
FAR-C (2) & 0.68 & $>100$ & $118836+11247 /-10237$ \\
FAR-C (3) & 0.68 & 62.8 & $118671+5738 /-5463$ \\
FAR-C (4) & 0.72 & 21.7 & $134132+9499 /-8769$ \\
RM-4 (1) & 0.59 & $>100$ & $95712+9860 /-9058$ \\
RM-4 (2) & - & 43.4 & $132199+4910 /-4702$ \\
RM-4 (3) & - & 15.7 & $138342+5214 /-4988$ \\
RM-4 (4) & - & 23.5 & $161371+8966 /-8311$ \\
RM-9 (1) & 0.87 & 180 & $198377+24525 /-20275$ \\
RM-9 (2) & 0.94 & - & $268291+44837 /-32127$ \\
RM-9 (3) & 0.79 & 95 & $168109+13152 /-11738$ \\
\hline
\end{tabular}

Sample RM-9 (2) provided a ${ }^{230} \mathrm{Th} /{ }^{234} \mathrm{U}$ ratio close to 1 , which, according to Horvatinčić et al. (2000), is due to uranium leaching and, therefore, should be rejected. Moreover, in this sample the uranium content was lower than the other samples from the same bed (RM-9) and Th was not measured.

Ages determined through amino acid racemization and U/Th were consistent, except for RM-4, in which rodoliths provided a mean age of ca. $130 \mathrm{ka}$, whereas Glycymeris shells gave $181 \pm 47 \mathrm{ka}$. However, it seems that weathering affected the RM-4 rodolith samples because the U/Th ages obtained were scattered. Only the age of sample RM-4(4) coincided with that obtained with the amino acid racemization method.

On the basis of these results, $P$. latus-bearing deposits correspond to MIS 7 and 5. The Torre García locality (TG) is the youngest one, probably because of the Glycymeris/Arca conversion but it can be included in MIS 5. 
Therefore, the dates reflect a 'Tyrrhenian Event', older than that which occurred during MIS 5. Similarly, Goy et al. (1986), Hillaire-Marcel et al. (1986), Causse et al. (1993), Zazo (1999) and Zazo et al. (2003), on the basis of U/Th dates from mollusc shells, and Hearty et al. (1986), using amino acid racemization ages, proposed that warm fauna (including P. latus) entered the Mediterranean Sea during MIS 7. Using C. caespitosa, Zazo et al. (2003) dated a bed bearing P. latus at La Marina Beach (Alicante, Spain) at ca. $180 \mathrm{ka}$ by U-series measurements. This is consistent with our results.

\section{Conclusions}

Our study reveals that high amounts of amino acids still remain on fossil $P$. latus shells. To ascertain the OM role we used the Mutvei's solution as well as SEM images, showing the growth episodes of the shells, thus demonstrating the problematic interpretation of the isotopic signal, as well as the irreability of the use of the $\mathrm{U} / \mathrm{Th}$ method for dating purposes in these molluscs. The main conclusions for each of the aspects studied are given below.

\section{Shell mineralogy}

The presence of a moderate content of calcite in fossil $P$. latus cannot be considered as an indicator of diagenesis. Extant strombid shells have discrete amounts of calcite in the shell. Higher calcite content in this mollusc shell could be linked to the seawater temperature, enough for the species to flourish but near the threshold of species survival. It does not seem to be any relationship between the shell chemistry and the phylogenetic relations of the taxa, as species from the Indo-West Pacific (L. lentiginosus and L. canarium) has either lower or higher calcite contents and similar to those from the Atlantic and eastern Pacific species (P. latus, L. gigas, L. raninus and $S$ alatus). Similarly, we observed a very thin protein-rich periostracum and the replacement of aragonite by calcite in the shell of different species. In some extant representatives $(P$. latus, L. raninus and L. lentiginosus), the inner layer of the shell was in contact with the nacre and consisted mostly of heterogeneous, cross-cutting fibrous lamellae perpendicular to the shell surface, and the in situ replacement of aragonite by calcite resulted in the preservation of the prismatic, fibrous aragonite structure.

The isotopical signal from adult strombids can be considered a mixture in unknown ratios of diverse stacked seasonal signals. The sawtooth oscillations of the $\delta^{18} \mathrm{O}$ values cited by many authors and found in our sample of $P$. latus reflect annual growth periods and provide a mixing of the first signal record (primary growth) and successive overgrowths. However, $\delta^{18} \mathrm{O}$ values cannot be used for seawater palaeotemperature determination. Our own data and those previously published reflect considerable isotopic variations in living individuals from the same locality, being greater in the fossil P. latus of our samples from Roquetas de Mar and samples from the Island of Majorca (Spain) and from Monastir (Tunisia) (see Cornu et al. 1993). However, marked differences were observed between the isotopic signal behaviour in recent and fossil shells. Therefore, further research is required to establish whether the geographical/environmental conditions made a crucial geochemical contribution to salinity variations in a basin (Mediterranean Sea) surrounded by landmasses and dominated by an arid climate in odd MIS.

\section{Organic matrix preservation}

The OM preservation, inferred from aspartic acid concentration, was exceptionally high in the fossils, showing similar values to extant representatives of other species in $60 \%$ of the samples. The lower contents can be explained by in situ weathering, in contrast to Bevelander \& Nakahara's (1975) results on pearls exposed to sea water for hundreds of years. Given that the $P$. latus shell was located in raised coastal lines in an almost dry environment, we consider that the OM was more effectively protected from the action of endolithic organisms.

The complex organic mineral fabric of strombid shells explains the high variability of $U$ and Th concentration along shell transects. This observation cannot be explained through a simple diffusive model cited in Dutton et al. (2005). Thus, the use of P. latus shells for $\mathrm{U} / \mathrm{Th}$ dating is unreliable.

\section{Chronology}

On the basis of the racemization ratios in Glycymeris sp., the P. latus-bearing beds from Roquetas de Mar, GA-12 and PEP belong to MIS 7 or the Cabezo de la Pella Event (Torres et al. 2000), while other localities (GA-15, FAR-C, TM-1, SGR, CTI-2, CTI-3 and CTI4) are clearly placed in MIS 5 . Our datings coincide with those of Goy et al. (1993). Other sites (TG, GA3, GA-10 and GA-14-1) can be placed either in MIS 7 or 5 . This finding indicates a two-step entrance of the Senegalese Faunal Complex into the Mediterranean realm as well as their climatostratigraphic character. 
Acknowledgements. - We are indebted to Dr Veronika Meyer of the University of Bern who helped in the setting up of our laboratory. Dr Glenn Goodfriend from the Carnegie Institution in Washington sent us the analysis protocol and GC program. The Biomolecular Stratigraphy Laboratory has been partially funded by ENRESA. We thank Dra Sonia Elsy Merino for the collections of living $P$. latus from Cabo Verde.

\section{References}

Abatino, E., Barbera Lamagna, C. \& Boni, M. 1971: Ultrastruttura e composicione chimica del guscio di Strombus bubonius Lk. (=S. Latus $\mathrm{Gm}$ ) viventes e fossile. Rendiconto dell'Accademia delle Scienze Fisiche e Matematiche di Napoli, Serie 4(XXVIII), $1-17$.

Auler, A.S. \& Smart, P.L. 2001: Late Quaternary paleoclimate in semiarid northeastern Brazil from U-series dating of travertine and water-table speleothems. Quaternary Research 55, 159-167.

Becker, A., Becker, W., Marxen, J.C. \& Epple, M. 2003: In-vitro crystallization of calcium carbonate in the presence of biological additives - comparison of the ammonium carbonate method with double diffusion techniques. Zeitschrift für anorganische und allgemeine Chemie 629, 2305-2311.

Belcher, A.M., Wu, X.H., Christensen, R.J., Hansma, P.K., Stucky, G.D. \& Morse, D.E. 1996: Control of cristal phase switching and orientation by soluble mollusc-shell proteins. Nature $381,56-58$.

Bevelander, G. \& Nakahara, H. 1975: Structure and amino-acid composition of pearls exposed to sea water for four hundred years. Herat Science 29, 87-91.

Bischoff, J.L. \& Fitzpatrick, J.A. 1991: U-series dating of impure carbonates: an isochron technique using total-sample dissolution. Geochimica et Cosmochimica Acta 55, 543-554.

Bischoff, J.L., Ludwig, K., García, J.F., Carbonell, E., Vaquero, M., Stafford, T.W. \& Jull, A.J.T. 1994: Dating of the Basal Aurignacian Sandwich at Abric Romaní (Catalunya, Spain) by Radiocarbon and Uranium-Series. Journal of Archaeological Science 21, 541-551.

Broecker, W.S. 1963: A preliminary evaluation of uranium series in equilibrium as a tool for absolute age measurements in marine carbonates. Journal of Geophysical Research 72, 4745-4757.

Causse, Ch., Goy, J.L., Zazo, C. \& Hillaire-Marcel, C. 1993: Potential chronologique (Th/U) des faunes Pléistocenes méditerranéennes: example des terrasses marines des regions de Murcie et Alicante (South-Est de l'Espagne). Geodinamica Acta 6, 121-134.

Cita, M.B., Capotondi, L. \& Asioli, A. 2005: The Tyrrhenian stage in the Mediterranean: definition, usage and recognition in the deep-sea record. A proposal. Rendiconti Fisica Accademia Lincei $16,297-310$.

Cornu, S., Pätzold, J., Bard, E., Meco, J. \& Cuerda-Barceló, J. 1993: Paleotemperature of the last interglaciar period based on $\mathrm{d} 18 \mathrm{O}$ of Strombus bubonius from the western Mediterranean Sea. Palaeogeography, Palaeodimatology, Palaeoecology 103, 1-20.

Cuerda, J. 1987: Moluscos Marinos y Salobres del Pletstoceno Balear, 421 pp. Caja de Baleares 'Sa Nostra', Mallorca.

Dauphin, Y., Guzmán, N., Denis, A., Cuif, J.P. \& Ortlieb, L. 2003: Microstructure, nanostructure and composition of the shell of Concholepas concholepas (Grastropoda, Muricidae). Aquatic Living Resources 16, 95-103.

Dutton, A., Eggins, S., Antonioli, F. \& Lambeck, K. 2005: Laser ablation U-Th daing of molluscan shells from Mediterranean interglaciar deposits. Available at: http://www.rses.anu.edu.au/ geodynamics/AnnRep/05/dutton 1.html.

Epstein, S. \& Lowenstam, H.A. 1953: Temperature shell-growth relations of recent and interglaciar Pleistocene shoal-water biota from Bermuda. Journal of Geology 61, 424-438.

Falini, G., Fermani, S., Gazzano, M. \& Ripamonti, A. 2000: Polymorphism and architectural crystal assembly of calcium carbonate in biologically inspired polymeric matrices. Joumal of the Chemical Society-Dalton Transactions 21, 3983-3987.

Feigl, F. 1937: Qualitative Analysis by Spot Tests, 400 pp. Nordermann Publishing Company, New York.
Ford, D.G. \& Schwarcz, H.P. 1981: Applications of stable isotope fractionation effects in waters, sedimentary deposits, flora and fauna. in Goudie A. (ed.): Geomorphological Techniques, 284287. Allen \& Unwin, London.

Friedman, G.M. 1959: Identification of carbonate minerals by staining methods. Journal of Sedimentary Petrology 29, 8797.

Giles, R., Manne, S., Mann, S., Morse, D.E., Stucky, G.D. \& Hansma, P.K. 1995: Inorganic overgrowth of aragonite on molluscan nacre examined by atomic force microscopy. Biological Bulletin 188, 8-15.

Gonfiantini, R. 1981: Stable isotope hydrology. IAEA Technical Report $210,35-84$.

González-Delgado, J.A., Zazo, C., Goy, J.L., Hoyos, M., Civis, J. \& Dabrio, C.J. 1998: Variaciones estacionales en Strombus bubonitus cuaternarios de Fuerteventura (Isals Canarias) a partir de perfiles de isótopos estables de C y O. XIV Jornadas de Paleontologia, Tenerife-La Laguna, 88-92.

González-Delgado, J.A., Goy, J.L., Zazo, C., Civis, J. \& Dabrio, C.J. 2000: Perfiles de isótopos estables de C y O en Strombus actuales, cuaternarios y pliocenos. XVI Jornadas de Paleontologia, Evora, 89-90.

Goodfriend, G.A. 1991: Patterns of racemization and epimerization of amino acids in land snail shells over the course of the Holocene. Geochimica et Cosmochimica Acta 55, 293-302.

Goodfriend, G.A. \& Meyer, V. 1991: A comparative study of the kinetics of amino acid racemization/epimerization in fossil and modern mollusc shells. Geochimica et Cosmochimica Acta 55, 3355-3367.

Goy, J.L., Zazo, C. \& Hillaire-Marcel, C. 1986: Stratigraphie et chronologie (U/Th) du Tyrrhénien du Sud-Est de l'Espagne. Zeitschrift für Geomorphology 62, 71-82.

Goy, J.L., Zazo, C., Bardají, T., Somoza, L., Causse, C. \& HillaireMarcel, C. 1993: Eléments d'une chronostratigraphie du Tyrrhénien des régions d'Alicante-Murcie, Sud-Este de l'Espagne. Geodinamica Acta 6, 103-119.

Guerreiro, A. 1994: Especial conchas deCabo Verde. Pesca e Mar 1, $16-18$.

Guerreiro, A. \& Reiner, F. 2000: Moluscos Marinhos da. Tha de Sao Vicente (Archipélago de Cabo Verde), 279 pp. Câmara Municipal de Oeiras, Portugal.

Harzhauser, M. \& Kronenberg, G. 2008: A note on Strombus coronatus Defrance, 1827 and Strombus coronatus Röding, 1798 (Mollusca: Gastropoda). The Veliger 50, 120-128.

Hearty, P.J. 1987: New data on the Pleistocene of Mallorca. Quaternary Science Reviews 6, 245-257.

Hearty, P.J., Miller, G.H., Stearns, C.E. \& Szabo, B.J. 1986: Aminostratigraphy of Quaternary shorelines in the Mediterranean Basin. Geological Society of America Bulletin 97, 850 858.

Hillaire-Marcel, C., Carro, O., Causse, C., Goy, J.L. \& Zazo, C. 1986: Th/U dating of Strombus bubonius bearing marine terraces in southeastern Spain. Geology 14, 613-616.

Hillaire-Marcel, C., Ghaleb, B., Gariépy, C., Zazo, C., Hoyos, M. \& Goy, J.L. 1995: U-series dating by the TIMS technique of land Snails from paleosols in the Canary Island. Quatemary Research $44,276-278$.

Hillaire-Marcel, C., Gariépy, C., Ghaleb, B., Goy, J.L., Zazo, C. \& Cuerda-Barceló, J. 1996: U-series measurements in Tyrrhenian deposits from Mallorca-further evidence for two last-interglacial high sea levels in the Balearic Islands. Quaternary Science Reviews $15,53-62$.

Horvatinčić, N., Čalić, R. \& Geyh, M.A. 2000: Interglacial growth of tufa in Croatia. Quaternary Research 53, 185-195.

Ivanovicht, M., Vita Finci, C. \& Henning, G.J. 1983: Uranium-series dating of molluscs from uplifted Holocene beaches in the Persian Gulf. Nature 302, 408-410.

Kai, A., Fujikawa, K. \& Miki, T. 2002: Vaterite stabilization in $\mathrm{CaCO}_{3}$ cristal by amino acid. Japanese Journal of Applied Physics $41,439-444$

Kamat, S., Su, X., Ballarini, R. \& Heder, A.H. 2000: Structural basis for the fracture toughness of the shell of the conch Strombus gigas. Nature 405, 1036-1040. 
Kaufman, A., Broecker, W.S., Ku, T.L. \& Thurber, D.L. 1971: The status of U-series methods of mollusc dating. Geochimica et Cosmochimica Acta 35, 1115-1183.

Kaufman, A., Ghaleb, B., Wehmiller, J.F. \& Hillaire-Marcel, C. 1996: Uranium concentration and isotope ratio profiles within Mercenaria shells: geochronological implications. Geochimica et Cosmochimica Acta 60, 3735-3746.

Kowalewski, M. \& Bambach, R.K. 2003: The limits of paleontological resolution. In Harries, P.J. (ed): High resolution approaches in stratigraphic paleontology: topic in geobiology series 21, 1-48. Plenum Press/Kluwer, New York.

Kowalewski, M., Goodfriend, G.A. \& Flessa, K.W. 1998: Highresolution estimates of temporal mixing within shell beds: the evils and virtues of time-averaging. Paleobiology 24, 287-304.

Kreipl, K. \& Poppe, G. 1999: A Conchological Iconography - The Family Strombidae, 59 pp. ConchBooks, Hackenheim.

Kronenberg, G.C. \& Lee, H.G. 2007: Genera of American strombid gastropods (Gastropoda: Strombidae) and remarks on their phylogeny. The Veliger 49, 256-264.

Kuhn-Spearing, L.T., Kessler, H., Chateau, E., Ballarini, R. \& Heder, A.H. 1996: Fracture mechanisms of the Strombus gigas conch shell: implications for de design of brittle laminates. Journal of Materials Science 31, 6583-6594.

Latiolais, J.M., Taylor, M.S., Roy, K. \& Hellberg, M.E. 2006: A molecular phylogenetic analysis of strombid gastropod morphological diversity. Molecular Phylogenetics and Evolution 41, 436444.

Lozac'hmeur, J.H. \& Mascarenhas, A. 1985: Pesca Artesanal Equipamentos e Materiais de Pesca. Reflexoes Sobre a Pesca em Cabo Verde Praia, 499 pp. Secretaria de Estado das pescas, Praia.

Marin, F., Corstjens, P., Gaulejac, B., Vrind-De Jong, E. \& Westbroek, P. 2000: Mucins and mollusca calcification. Journal of Biological Chemistry 275, 20667-20675.

Marin, F., Amons, R., Guichard, N., Stigter, M., Hecker, A., Luquet, G., Layrolle, P., Alcaraz, G., Riondet, C. \& Wetbroek, P. 2005: Caspartin and calprismin, two proteins of the shell calcitic prisms of the Mediterranean fan mussel Pinna nobilis. Journal of Biological Chemistry 280, 33895-33908.

McCrea, J.M. 1950: On the isotope chemistry of carbonates and a paleotemperature scale. Journal of Chemical Physics 18, 849-857.

Meco, J. 1977: Paleontología de Canarias, 142 pp. Excelentísimo Cabildo Insular de Gran Canaria, Gran Canaria.

Mendes-Lopes, R.C. 2002: Caracterizacao da Pesca de Búcio-cabra (Strombus latus Gmelin, 1971) na Itha de Sao Vicente, Cabo Verde, 44 pp. Unpublished MS Thesis, University of El Algarbe.

Milliman, J.D. 1974: Marine Carbonates, 375 pp. Springer Verlag, Berlin.

Miyamoto, H., Miyashita, T., Okushima, M., Nakano, S., Morita, T. \& Matsushiro, A. 1996: A carbonic anhydrase from the nacreous layer in oyster pearls. Proceedings of the National Academy of Science USA 93, 9657-9660.

Mutvei, H., Westermark, T., Dunca, E., Carell, B., Forsberg, S. \& Bignert, A. 1994: Methods for the study of environmental changes using the structural and chemical information in molluscan shells. Past and present biomineralization processes, considerations about the carbonate cycle. Bulletin du Musée Océanographique de Monaco, Special Number 13, 163-919.

Nassif, N., Pinna, N., Gehrke, N., Antoniet, M. \& Cölfen, H. 2005: Amorphous layer around aragonite pletelets in nacre. Proceedings of the National Academy of Science USA 102, 1265312655.

Ortiz, J.E., Torres, T., Delgado, A., Julià, R., Llamas, F.J., Soler, V. \& Delgado, J. 2004a: Numerical dating algorithms of amino acid racemization ratios analysed in continental ostracodes of the Iberian Peninsula (Spain). Application to Guadix-Baza Basin (southern Spain). Quaternary Science Reviews 23, 717-730.

Ortiz, J.E., Torres, T., Julià, R. \& Llamas, J.F. 2004b: Algoritmos de cálculo de edad a partir de ratios de racemización de aminoácidos de pelecípodos marinos del litoral español. Revista de la Sociedad Geológica de España 17, 213-224.

Pokroy, B., Quintana, J.P. \& Zolotoyabko, E. 2000: Structural distinctions between biogenic and geological aragonite. Materials Research Society Symposium Proceedings 874, 1-6.
Pokroy, B., Zolotoyabko, E. \& Adir, N. 2006: Purification and functional análisis of a $40 \mathrm{D}$ protein extracted fron the Strombus persicus mollusc shells. Biomacromolecules 7, 550-556.

Rehman, J., Jones, B., Hagan, T.H. \& Coniglio, M. 1994: The influence of sponge borings on aragonite-to-calcite conversion in Late Pleistocene Strombus gigas from Grand Cayman, British West Indies. Journal of Sedimentary Research A 64, 174-179.

Rosenbauer, R.J. 1991: UDATEl: a computer program for the calculation of uranium-series isotopic ages. Computers and Geosciences 17, 45-75.

Samata, T. 1990: Co-binding glycoproteins in molluscan shell with different types of ultrastructure. The Veliger 33, 191-201.

Samata, T. 2004: Recent adavances in studies on nacreous layer biomineralization. Molecular and cellular aspects. Thalassas 20 , 25-44.

Sarashina, I. \& Endo, K. 2001: The complete primary structure of molluscan shell protein (MSP-1) an acidic glycoprotein in the shellmatrix of the scallop Patinopecten yessoensis. Marine Biotechnology 3, 362-369.

Schöne, B.R., Dunca, E., Fiebig, J. \& Pfeiffer, M. 2005: Mutvei's solution: an ideal agent for revolving microgrowth structures of biogenic carbonates. Palaeogeography, Palaeoclimatology, Palaeoecology $228,149-166$.

Schultz, L.G. 1964: Quantitative interpretation of mineralogical composition from X-ray and chemical data from the Pierre Shale. US Geological Survey Professional Paper 391(C), 1-31.

Schwarcz, H.P. 1980: Absolute age determination of archaeological sites by Uranium series dating of travertines. Archaeometry 22, $3-24$.

Shen, X., Belcher, A.M., Hansma, P.K., Stucky, G.D. \& Morse, D. 1997: Molecular cloning and characterizatgion of lustrin A, a matriz protein from shell and peral nacre of Haliotis rufescens. Journal of Biological Chemistry 272, 3247232481 .

Stein, M., Wassenburg, G.J. \& Lajoie, K.R. 1991: U-series ages of solitary corals from the California coast by mass spectrometry. Geochimica et Cosmochimica Acta 57, 3709-3722.

Stein, M., Wassenbourg, G.J., Chen, J.H. \& Zhu, Z.R. 1993: TIMS $\mathrm{U}$-series dating and stable isotopes of the last interglaciar events in Papua New Guinea. Geochimica et Cosmochimica Acta 57, 2541-2554.

Stoner, W.A. 1994: Significance of habitat and stock pre-testing for enhancement of natural fisheries: experimental analyses with queen conch Strombus gigas. Journal of the World Aquaculture Society 25, 155-165.

Sudo, S., Fujikawa, T., Nagakura, T., Ohkubo, T., Sakaguchi, K., Tanaka, M., Nakashima, K. \& Takahashi, T. 1997: Structures of mollusc shell framework proteins. Nature 387, 563-564.

Swart, P.K., Burns, S.J. \& Leder, J.J. 1991: Fractionation of the stable isotopes of oxygen and carbon in carbon dioxide during the reaction of calcite with phosphoric acid as a function of temperature and technique. Chemical Geology 86, 89-96.

Thomson, J.B., Paloczi, G.T., Kindt, J.H., Michenfelder, M., Smith, B.L., Stucky, G., Morse, D.E. \& Hansma, P.K. 2000: Direct observation of the transition from calcite to aragonite growth as induced by abalone shell proteins. Biophysical Journal 79, 33073312.

Tong, H., Ma, W., Wang, L., Wan, P., Hu, J. \& Cao, L. 2003: Control over the crystal phase, shape, size and aggregation of calcium carbonate via a L-aspartic acid inducing process. Biomaterials 25, 3923-3929.

Torres, T., Llamas, J.F., Canoira, L., García-Alonso, P., GarcíaCortés, A. \& Mansilla, H. 1997: Amino chronology of the Lower Pleistocene deposits of Venta Micena (Orce, Granada, Andalusia, Spain). Organic Geochemistry 26, 85-97.

Torres, T., García-Alonso, P., Canoira, L., Llamas, J.F. \& Ortiz, J.E. 2000: Aminostratigraphy of two Pleistocene marine sequences from the Mediterranean coast of Spain: Cabo de Huertas (Alicante) and Garrucha (Almería). In Goodfriend, G.A., Collins, M.J., Fogel, M.L., Macko, S.A. \& Wehmiller, J.F. (eds): Perspectives in Amino Acids and Protein Geochemistry, 263-278. Oxford University Press, New York. 
Wada, N., Okazaki, M. \& Tachikawa, S. 1993: Effects of calciumbinding polysaccharides from calcareous algae on calcium carbonate polymorphs Ander conditions of double difusión. Journal of Crystal Growth 132, 115-121.

Wefer, G. \& Killingley, J.S. 1980: Growth histories of strombid snails from Bermuda recorded in their O-18 and C-13 profiles. Marine Biology 60, 129-135.

Wehmiller, J.F. 1984: Interlaboratory comparison of amino acid enantiomeric ratios in fossil molluscs. Quaternary Research 22, 109-120.

Weiner, S. 1979: Aspartic acid-rich proteins: major components of the soluble organic matrix of mollusc shells. Calcified Tissue International 29, 163-169.
Weiner, S. 1984: Organization of the organic matrix components in mineralized tissues. American Zoologist 24, 945-951.

Weiner, S. \& Hood, L. 1975: Soluble protein of the organic matrix of mollusc shells: a potential template for shell formation. Science 190, 987-989.

Zazo, C. 1999: Interglacial sea levels. Quatemary International 55, 101-113.

Zazo, C., Goy, J.L., Dabrio, C.J., Bardaji, T., Hillaire-Marcel, C., Ghaleb, B., González-Delgado, J.A. \& Soler, V. 2003: Pleistocene raised marine terraces of the Spanish Mediterranean and Atlantic coasts: records of coastal uplift, sea-level highstands and climate changes. Marine Geology 194, 103-133. 